\title{
Optical Properties of Sodium Nitrate in the Vacuum Ultraviolet Region(Abstract_要旨)
}

$\operatorname{AUTHOR}(S)$ :

Yamashita, Hiroshi

\section{CITATION:}

Yamashita, Hiroshi. Optical Properties of Sodium Nitrate in the Vacuum Ultraviolet Region. 京都大学, 1973, 理学博士

\section{ISSUE DATE:}

1973-01-23

URL:

http://hdl.handle.net/2433/219919

RIGHT: 


\section{【45】}
氏 名
や居博 志
学位の種類
理学 博士
学位記 番号
理 博 第 268 号
学位授与の日付
昭和 48 年 1 月 23 日
学位授与の要件
学 位規則第 5 条第 1 項該当
研究科・専攻
理学研究科物理学第一専攻
学位論文題目

\section{Optical Properties of Sodium Nitrate in the Vacuum Ultraviolet Region}

（真空紫外域での硝酸ナトリウムの光学的性質）

（主 查）

論文調查委員教授 中井祥夫教 授 浅井健次郎 教 授 端 恒 夫

\section{論文内容 の要旨}

本論文は硝酸ナトリウム $\left(\mathrm{NaNO}_{3}\right)$ の光学的性質を調べることにより，分子性イオン基を持つ異方性イ オン結晶であるというこの物質の特徵が，その電子状態にどの様に反映されるかを笑験的に解明する事を 意図している。

硝酸アルカリ $\left(\mathrm{ANO}_{3}\right)$ の蒸着膜による吸収スペクトルでは約 $6 \mathrm{eV} に \mathrm{NO}_{3}{ }^{-}$の分子内遷移に伴う吸収 帯 ( $\mathrm{S}_{1}$ 带) が観测され，又高エネルギー側 $10 \sim 12 \mathrm{eV}$ 領域には $\mathrm{NO}_{3}^{-}$から金属イオンにともなう準位へ の電子移動による二つの吸収帯 $\left(\mathrm{S}_{2}, \mathrm{~S}_{3}\right.$ 带) が観測される。本論文では硝酸アルカリのうち, 結晶構造が 比較的簡単で，かつ単結晶の作り易い物質としてカルサイト型構造 $\left(\mathrm{D}_{3 \mathrm{~d}}{ }^{6}\right)$ を持つ $\mathrm{NaNO}_{3}$ に注目し，そ の単結晶について偏光反射測定を行い，吸収スペクトルに見られる上述の吸収带に関して偏光依存性及び 吸収強度を決定し，電子遷移の同定を行っている。

上記 $\mathrm{S}_{1}$ 特よび $\mathrm{S}_{2}$ 両带は真空紫外部にある為，通常用いられる透過型偏光子及び検光子の使用は不可 能である。この為, $\mathrm{KCl}$ 単結唱の擬ブリュースタ一角 $\left(\sim 60^{\circ}\right)$ に拈ける反射によって得た偏光を光源と し，偏光度は金コートした鏡の $45^{\circ} に$ 扮ける反射率の测定から求めている。反射率测定は $\mathrm{NaNO}_{3}$ 単結唱 の研摩面及び䢃開面について行なわれたが，研摩面については反射率の低下及び再現性の悪さからデータ の信頼性に欠汀る事，他方擘開面では反射率が高く，再現性にも富む事が判明した。従って本諭文に招い ては，反射率の測定は主として辟開面について行なわれている。

$\mathrm{NaNO}_{3}$ の䢃開面は C 軸に対して $43^{\circ} 49^{\prime}$ 傾いた (1011) 面であるが，この面の常光線及び異常光線に対 する反射率 (Ro, $\left.\mathrm{Re}^{\prime}\right)$ の Kramers-Kronig 解析から先ず複素誘電率の組 $\left(\varepsilon_{0}, \varepsilon_{\mathrm{e}}^{\prime}\right)$ が決まる。ここで常 光線に対する誘電率 $\varepsilon_{\mathrm{o}}$ はそのままC 軸に值角な方向に対する主誘電率であるが，C軸力句の主誘電率 $\varepsilon_{\mathrm{e}}$ は一定の関係式を用いて異常光線側の誘電率 $\varepsilon_{\mathrm{e}}^{\prime}$ から求める事が出来る。

以上の測定及びデータの解析から得られた結論は以下に示すようなものである。

(1) $\mathrm{NaNO}_{3}$ 単結晶の䢃開面に対する反射率を測定する事により信頼性の高い光学定数が得られた。又, 
得られたスペクトルの形状は蒸着膜による四収スペクトルの測定結果ともよく一致する。

(2) $\mathrm{S}_{1}$ 帯は常光線 $(\mathrm{E} \perp \mathrm{C})$ に対して活性であり，その振動子強度は局所場補正を行った結果 $\mathrm{NO}_{3}^{-}$分 子当り 0.49 となった。この值は孤立した $\mathrm{NO}_{3}{ }^{-}$に対して McEwen が分子軌道法で計算した值（f= 0.34) ともほぼ一致する。従ってこの吸収带は $\mathrm{NO}_{3}{ }^{-}$の $\pi_{2} \rightarrow \pi^{*}\left(\mathrm{~A}_{1}{ }^{\prime} \rightarrow \mathrm{E}^{\prime}\right)$ なる分子内遷移によるも のであるという事が出来る。

(3) $\mathrm{S}_{2}$ 帯は常光線に対して活性であり, $\mathrm{NO}_{3}{ }^{-}$に招いてェネルギー的に接近した二つの分子軌道 $\mathrm{n}_{1}\left(\mathrm{a}_{2}{ }^{\prime}\right)$ 及び $\mathrm{n}_{2}\left(\mathrm{e}^{\prime}\right)$ のうち $\mathrm{n}_{2}\left(\mathrm{e}^{\prime}\right)$ 軌道にともなう準位から $\mathrm{Na}^{+}-3 \mathrm{~s}$ 軌道にともなう準位への電子遷移に対 応するものである。

\section{論文審 査の結 果の要旨}

申請論文は硝酸ナトリウム $\left(\mathrm{NaNO}_{3}\right)$ の単結晶について偏光反射スペクトルの測定から光学定数を決定 し，結晶中での電子状態についての考察を試みたものである。

硝酸ナトリウムは約 $6 \mathrm{eV} に \mathrm{NO}_{3}{ }^{-}$に固有の吸収带を持つが，本論文に执いてはこの吸収帯が常光線， 即ち $\mathrm{NO}_{3}$ - 分子の平面内で振動する偏光に対して活性である事が明らかにされ, その振動子強度は $\mathrm{NO}_{3}{ }^{-}$

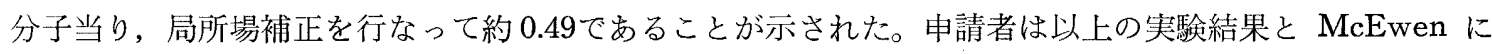
よる $\mathrm{NO}_{3}{ }^{-}$に対する分子軌道計算との対応から，この吸収帯を $\mathrm{NO}_{3}^{-}$の $\pi_{2} \rightarrow \pi^{*}\left(\mathrm{~A}_{1}{ }^{\prime} \rightarrow \mathrm{E}^{\prime}\right)$ なる分子内遷 移によるものと同定した。次に，高エネルギー側約 $10 \mathrm{eV}$ に見られる吸収带もその偏光依存性が常光線に 対して活性である事から，この吸収帯をエネルギー的に接近した $\mathrm{NO}_{3}{ }^{-}$の二つの分子軌道 $\left(\mathrm{n}_{1}\left(\mathrm{a}_{2}{ }^{\prime}\right), \mathrm{n}_{2}\right.$ $\left.\left(\mathrm{e}^{\prime}\right)\right)$ のうち, $\mathrm{n}_{2}\left(\mathrm{e}^{\prime}\right)$ 軌道から $\mathrm{Na}^{+}-3 \mathrm{~s}$ 軌道への電子移動に伴う遷移であるとの同定を行なった。

$\mathrm{NaNO}_{3}$ は光学材料として重要な物質であり, 可視及び紫外部に拈いて強い複屈折性を示すが, その原 因が約 $6 \mathrm{eV}$ に位置する $\mathrm{NO}_{3}^{-}$の分子内遷移による事，及び $\mathrm{NO}_{3}^{-}$分子の結晶内での整列配向による事 が本論文に扣いて明らかにされた事は意義深い。又，本実験に扔いて主光学定数を求める際に用いられた 手法は本研究独自のもので, この方法は光学主軸に対してかたむいた䢃開面を持つ他の一軸性結晶につい ても適用可能である。

申請者は従来よりイオン基を持つイオン結晶の電子状態に興味を持ち, 第一段階として先ず蒸着膜につ いて硝酸アルカリの吸収スペクトルを測定し，それにつづいて本論文においては初期の吸収測定から得ら れた定性的な知見に基き， $\mathrm{NaNO}_{3}$ 単結晶の反射スペクトルから信頼性の高い光学定数を決定すると共 に電子状態について更に一歩進んだ解析を行なった。これ等の結果にもとづいて，硝酸アルカリの電子状 態に関して，イオン基に固有な特徵およびイオン結晶に固有な特徵の両方が現われている事を明らかにし た。

上述の様に本研究では光物性の分野に扔いて従来は余り取上げられなかった物質である分子性イオン結 晶を対象として，イオン結晶及び分子性結晶の双力にまたがる特性を正確に把握すると共に, 硝酸アルカ リに見られる強誘電性，相転位等の興味ある現象に関しても，光物性的研究に対する基礎的な資料を提供 するものである。

これ等の事は申請者が物性物理の分野, 特に真空紫外領域に括汗る光物性の分野において，広い知識と 
独創的な研究能力を持つことを示している。又, 本論文によって得られた結果は固体中の電子状態に関し て新しい知見を加えるものであり，物性物理学の発展に寄与するところが少なくない。

よって，本論文は理学博士の学位論文として佻值あるものと認める。 